\title{
Ideologies in Mandela's No Easy Walk to Freedom
}

\author{
Ali AbdulhameedFaris \\ Dept of English, Faculty of Modern Languages and Communication, Universiti Putra Malaysia, Malaysia \\ E-mail: alifares1966@yahoo.com \\ Shamala Paramasivam (Corresponding author) \\ Dept of English, Faculty of Modern Languages and Communication, Universiti Putra Malaysia, Malaysia \\ E-mail: shamala@upm.edu.my
}

Received: 28-03-2016

Published: 01-09-2016
Accepted: 07-06-2016

doi:10.7575/aiac.ijalel.v.5n.5p.49
Advance Access Published: July 2016

URL: http://dx.doi.org/10.7575/aiac.ijalel.v.5n.5p.49

\begin{abstract}
Ideology has great influence on the traits and behaviors of leaders. It is the vehicle by which we could understand our leaders and our leaders could understand us. The present paper is an endeavor to reveal the ideological dimension that is embedded in the discourse of Nelson Mandela, with special reference to his address No Easy Walk to Freedom which was delivered in 1953. It is conducted on the approach of Critical Discourse Analysis. Van Dijk's (2004) Political Ideological Strategies and Wodak's (2005) Discursive Strategies of Positive Self- and Negative Other-Presentation were accommodated to achieve the objective of the study. The findings demonstrated that Van Dijk's strategies of actor description, positive self-presentation and negative other-presentation and Wodak's two chosen strategies of argumentation and perspectivation were supportive in exploring the ideologies penetrated in Mandela's discourse. They five strategies proved to be helpful devices in exploring the fundamentally embedded ideologies in Mandela's discourse which are "white superiority" and "black inferiority". White superiority was the ideological foundation of the white minority to establish the apartheid system in South Africa for decades, whereas black inferiority was the ideological foundation of the black majority to sustain different forms of resistance against the white governments. Therefore, it could be perceived that the social acts of both the blacks and the whites were formed and structured in terms of these two ideological foundations.
\end{abstract}

Keywords: Critical Discourse Analysis, Ideology, Political Discourse, Nelson Mandela

\section{Introduction}

The term ideology has been tackled amid considerable controversy. Kress (1985) acknowledges that it is difficult to pin down the term ideology which is considered one of the more controversial topics in the fields of philosophy and sociology. Similarly, Wodak (2007) believes that ideology is regarded as one of the thorniest terms of opinions and beliefs. Van Dijk (1998) views that ideology remains fuzzy and unsettled and researchers admit to the vagueness of this notion and the confusion of its theoretical analysis. However, Kress (1985, p. 29) demonstrates that the term ideology has been subjected to different accounts in that it has extended from the innocuous set of beliefs and ideas to the more controversial ones such as the "false consciousness", or the "ideas of the dominant ruling class". Wodak (2007, p. 2) tackles the modern debates on ideology by considering two main strands. The first is that "Ideologies as false theories about reality can be overcome and replaced by scientific theories and/or scientifically founded agency", whereas the second assumes the "dialectical" notion by viewing "ideology" as being an unavoidable moment in the process of thinking and acting.

Some linguists believe that political discourse is basically ideological. Van Dijk (1998), for example, looks upon political discourse as not merely a genre. Rather it is a class of genres which involves a variety of political activities; each activity is considered to be a genre. On this basis, parliamentary arguments, cabinet meetings, speeches of politicians, and party conferences and programs are all examples of the different genres that are related to the domain of politics. He views that political discourse is not only restricted to political ideologies but also involves ideologies that pertain to ecology, feminism and racism or which are considered to be part of political ideologies although they are not purely politics. According to him, political discourse is a medium through which politicians legitimize and enact their multiple identities; therefore, they are found speaking on conservatism or liberalism, feminism or anti-feminism, racism or anti-racism.

Abercrombie and Hill (1980) and Van Dijk (2004) believe that not only the dominant group have ideologies but even the dominated whose ideologies are often of resistance and opposition. On this basis, it could be concluded that ideologies are representations of the interests of social groups, classes or communities. Accordingly, the term ideology in the context of the current paper is tackled in terms of the ideologies underlined in the discourse of the dominated group represented by the discourse of Nelson Mandela. The current work advocates Van Dijk's (2004) and Wodak's (2005) views on ideological beliefs, both of which are discussed in further detail in section 3. 


\section{Research Objectives}

Having gone through literature on the concept of "ideology" in the discourse of non-western leaders, it has been found that it is an area which has not got adequate research and it is still a point of debate and discussion. Based on this view, the current study is a critical endeavor to explore the underlying discursive ideologies in the discourse of the nonwestern political leader, Nelson Mandela, who, via the beliefs, values and attitudes he shared with his masses and communicated to them, succeeded in constructing his iconicity as one of the most important global figures. Despite the fact that there is intensive research conducted on this leader that most of it is centered around his early life, personal characters, leadership, ideals, charisma, trial, imprisonment, and presidency, there is still rare research conducted on the linguistic insights of the discourse of this leader, namely his discursively ideological attitudes. The objective of the present study; therefore, is to linguistically examine the ideological attitudes embedded in his discourse with particular reference to No Easy Walk To Freedom, a speech which was delivered before his imprisonment. This study is an attempt to extend the findings of a study conducted by Faris, Paramasivam, Tan and Abdul (2016) on persuasive strategies in Mandela's No Easy Walk to Freedom. It is part of a large study which aims to investigate the role of ideologies in producing and shaping Mandela's discourse across the four stages of his political career, before his imprisonment, after his imprisonment, during his presidency, and during his retirement.

\section{Related Literature}

The main concern of critical discourse analysis (CDA) is to study and analyze written and spoken texts so as to reveal the discursive practices of power, dominance, oppression, solidarity and ideology (Van Dijk, 1998; Johnstone, 2008). Through systematic study of the interconnection between discourse and social and cultural practices, awareness of communication would be elevated and; therefore, more understanding, tolerance and fewer problems would be established (Georgakopoulou \& Goustsos, 1997). Wodak (2007) states that CDA is distinctive in its two perspectives, the interconnection between language and society and the relationship between analyses and the social practices that are analyzed. The approach of CDA is; therefore, adopted in this study to highlight the underlying ideologies which constitute the discourse of Mandela and which are constituted by it. As a theoretical framework for the whole study, Fairclough's (1989) approach of CDA has been accommodated to help explore ideology which is beyond the linguistic perspective. It involves three stages of discourse analysis:

1. Description: this stage is interested in highlighting the formal properties of text. At this stage, the critical discourse analyst is concerned with studying the formal properties of discourse, such as vocabulary, textual structure and grammar.

2. Interpretation: this stage tackles the relationship between text and discourse analysis. Interpretations are generated dialectically in terms of the interpreter's background knowledge.

3. Explanation: this stage is concerned with describing discourse as a social practice or social process. It shows how the interconnection between discourse and social structures is determined.

Ideologies, according to Van Dijk (2001, 1998), are manifested in the activities of people who interact in society as members of social groups. Accordingly, different forms of domination can be found between variant groups of members. Women may be found discriminated by men, the black could be found dominated by the white, the poor may be excluded and disregarded by the rich, and the aged could be found ignored and marginalized by the young. These different forms of discrimination are supposed to be penetrated in text and talk. Relevantly, ideologies are not only ingrained in the verbal activities, but also in the paraverbal activities, such as gestures, facial expressions, etc. Thus, the interaction between members who belong to different ethnic, racial, religious, and political groups would give rise to the underlying ideologies which characterize each group. Against such background, it is highly expected to find members of one group practicing marginalization, exclusion, and degradation against members of another group. In such a case the members of the dominated group could be deprived of their basic rights, such as having jobs, expressing thought, having homes, having education, etc. What is significant to realize at this point is that all these forms of discrimination and domination are embodied in discourse.

The members of a group are characterized by specific social behaviors and attitudes and specific mental models. They constitute what is called by Fairclough (1995), Van Dijk (1998, 2004) and Wodak (2005) the in-group which is a prototype of cohesion, coordination and cooperation. The identification of the in-group is syllogistically an identification of the out-group which is, meanwhile, characterized by its own social representations and, henceforth, by its own ideologies. Van Dijk (1998, 2004) and Wodak (2005) believe that accounting for ideological discourse is to be based on social representations between groups. Political discourse is, thus, viewed by Fairclough (1995), Van Dijk $(1998,2004)$ and Wodak (2005) as a form of social activity and social representation.

Van Dijk (2004) views that discourse, ideology and politics are interconnected, that is both politics and ideologies are discursive. Ideologies play an influential role in politics, specifically in defining political entities (systems, organizations, movement). To emphasize our good things and their bad things, and to de-emphasize our bad things and their good things is considered, by Fairclough (1995), Wodak (2004, 2008), and Van Dijk (1998, 2001, 2004), as a strategy to express the underlying ideologies in political discourse. Van Dijk $(1998,2004)$ suggests a number of strategies for ideological analysis. They can be utilized for analyzing racist and anti-racist ideologies in the speeches of particular members of the British House of Commons. Van Dijk (2004) states that these strategies are not limited to only racist or anti-racist ideologies; they are applicable to different types of ideologies. In the present study, they are used to reveal the underlying ideologies in the political speeches of Nelson Mandela. However, it could be realized that 
not all of them are appropriate to analyze the ideologies under examination because some of them have been formulated by Van Dijk (2004) to be mostly pertinent to the issue of immigration seekers to Britain. Therefore, the present study has excluded the strategies that are pragmatically inapplicable to the investigation of the ideologies in the speeches under study and included only those which are pragmatically relevant to the nature of ideologies embedded in the discourse under investigation. They are expressed as follows:

\section{a. Actor Description:}

This strategy refers to the different types of actor description which are involved in all discourses about people and their actions. In discourse, actors are described either as members of group or as individuals. They are described by the first name, the name of the family, the name of the group, or the role of the group. They may also be referred to in terms of their actions, attributes, position, or relations to other people. Actors, in discourses, are described and evaluated in terms of ideologies. The in-group members are described positively, whereas the out-group members are described negatively since positive self-presentation and negative other-presentation is a general ideological strategy in discourse. An example of actor description can be recognized in the discourse of the British House of Commons member, Mrs. Gorman, who negatively describes a Romanian asylum seeker by stating:

In one case, a man from Romania, who came over here on a coach tour for a football match decided that he did not want to go back, declared himself an asylum seeker and is still here four years later. He has never done a stroke of work in his life

$$
\text { (Van Dijk, 2004, p. 17). }
$$

b. Negative-Other Presentation: it is an overall strategy which is based on derogating the out-groups. It is ideologically based because people are usually categorized into in-group and out-group, a categorization or division that is based on socially shared ideologies and attitudes. Based on this conception, speakers raise the bad properties and things of the out-group. Van Dijk (2004, p, 21) gives an example of "negative-other presentation" when he refers to the description that Mrs. Gorman has given about the asylum seekers (see example in (a) above. She describes them as "benefit seekers".

c. Positive Self- Presentation: it is a strategy that is purely ideological as it is based on defining, praising, and favoring the in-group. This strategy may take either individual form when the speaker emphasizes his own positive characteristics or exploits, or collective form when he focuses on the positive characteristics of his group which might be his own party or country. This strategy also involves the references that speakers make when raising their principles, history and traditions. Mrs. Gorman produces an example of the positive self-presentation by saying:

I entirely support the policy of the Government to help genuine asylum seekers, but...

(Van Dijk, 2004, p. 22).

Wodak (2005) suggests five types of discursive strategies for ideological analysis. Discursive strategy refers to the systematic ways of using language and can be adopted to implement certain aims: social, political, psychological or linguistic (Wodak2005). According to her, discursive strategies are involved in the notion of positive self- and negative other-presentation and they are based on the construction of "Us" and "Them":

a. Referential Nomination: the aim of this strategy is to construct the in-groups and the out-groups. The main device of this strategy is membership categorization. An example of this strategy is obvious in the following excerpt from the speech of Tony Blair, the former Prime Minister of the United Kingdom, where he categorizes two groups, the Iraqi regime as out-group which is described as a dictatorial regime that has tyrannized and brutalized its people, and Britain and the world as in-group which confronts the central security threat of the out-group (the Iraqi regime):

So: Why does it matter so much? Because the outcome of this issue will determine more than the fate of Iraqi regime and more than the future of the Iraqi people, for so long brutalized by Saddam. It will determine the way Britain and the world confront the central security threat of the $21^{\text {st }}$ century

(Tony Blair, March 18, 2003, www.theguardian.com).

b. Predication: the objective of this strategy is to label the social actors negatively or positively. Definitely the in-group members are described positively, whereas the out-group ones are described negatively. Therefore, evaluating attributions of negative or positive traits is the device of this strategy. An example of this strategy can be found in the following excerpt from the speech of Tony Blair where he describes negatively the out-group, represented by Saddam Hussein who was the president of the Iraqi regime, by utilizing the metaphor "evil":

Looking back over 12 year, we have been victims of our own desire to placate the implacable, towards reason the utterly unreasonable, to hope that there was some genuine intent to do good in a regime whose mind is in fact evil.

(Tony Blair, March 18, 2003, www.theguardian.com.).

c. Argumentation: the objective of this strategy is to justify or legitimize positive or negative attributions. Justifying political inclusion or exclusion is the device of this strategy. In the following text, for example, Margaret Thatcher, the Prime Minister of the United Kingdom, argues the problem of unemployment in England at the outset of the 1980s and tries to justify why it is not so easy to deal with such a problem: 
If I could press a button and genuinely solve the unemployment, do you think that I would not press that button this instant? Does anyone imagine that there is the smallest political gain in letting this unemployment continue, or that there is some obscure economic religion which demands this unemployment as part of its rituals? This Government are pursuing the only policy which gives any hope of bringing our people back to real and lasting employment

(Thatcher, October 10, 1980, www.margaretthatcher.org).

d. Perspectivation: the aim of this strategy is to express the involvement of the speaker. The device of this strategy is reporting, describing, narrating, or quoting events and utterances. In an attempt to create involvement, Obama, in the following text, narrates an incident and quotes utterances:

Some years ago, Rebekah and Ben Erler of Minneapolis were newlyweds. She waited tables. He worked construction. Their first child, Jack, was on the way. They were young and in love in America, and it does not get much better than that. "If only we had known", Rebekah wrote to me last Spring, "What was about to happen to the housing and construction market." As the crisis worsened, Ben's business dried up, so he took what jobs he could find, even if they kept him on the road for long stretches of time.....

(Obama, January 20, 2015, www.mediaite.com).

e. Intensification or Mitigation: the objective of this strategy is to express if the utterances are stated explicitly or implicitly, if they are intensified or mitigated. The devices of this strategy are to intensify or mitigate utterances. An example of this strategy can be seen in the following excerpt from the speech of Tony Blair where he intensifies his proposition concerning an issue that Britain faces; intensification is performed throughout the emphatic employment of the question, "But why does it matter so much?":

The question most often posed is not why does it matter? But why does matter so much? Here we are, the government with its most serious test, its majority at risk, the first cabinet resignation over an issue of policy. The parties divided

(Blair, March 18, 2003, www.theguardian.com).

In the context of the present study, only Wodak's (2005) strategies of Argumentation and Perspectivation are adopted as there is an overlap between her strategies of Referential nomination, Predication and Intensification or mitigation with Van Dijk's (2004)strategies of political ideological analysis. Figure 1 illustrates the theoretical framework of this study.

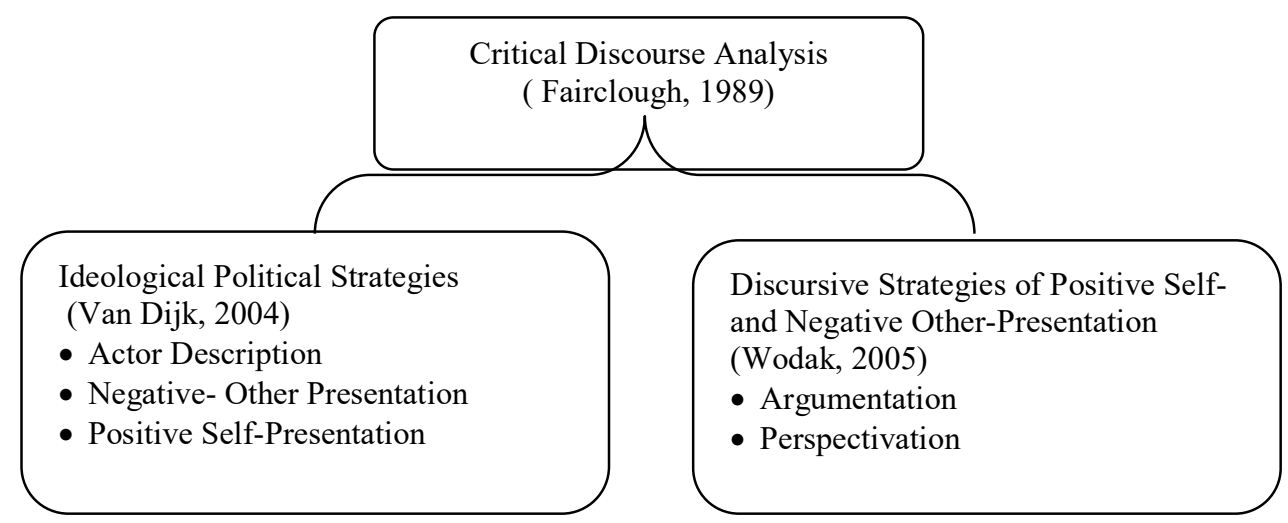

Figure 1. Theoretical Framework of the Study

\section{Methodology}

The present study attempts to highlight the interconnection between discourse, ideology and politics. It is qualitative in nature and it reflects on the conventions of Critical Discourse Analysis as a method of data analysis. Having been qualitative study involving mostly non-statistical approach of data analysis (Merriam, 2009), the present paper is orientated towards a selection of material which can be done manually. The unit of analysis in this study encompasses words, phrases, clauses, sentences, and the total speech act vis-à-vis the total speech situation. Discourse analysis, according to Coulthard (1977) and Stubbs (1983) is an attempt to examine how language use can be absorbed in various social contexts. It is supposed to decipher the meaning of words, phrases, and clauses that a sentence is composed of and to go beyond the boundaries of sentence to tackle the whole text in connection to the exterior world.

For the ideological analysis, Van Dijks' (2004) Political Ideological Strategies and Wodak's Discursive Strategies of Positive Self- and Negative-Other Presentation comprised the analytical framework. Lexical repetition (of nouns and adjectives), which is a cohesive tool in discourse (Halliday \& Hassan, 1976), and meaning relations (of synonymous and antonymous nouns and adjectives), which are predictive and reflective in all types of discourse (Fairclough, 1989, were accommodated in this study as helpful linguistic devices to uncover the ideologies embedded in the speech under investigation. Table 1 in Appendix displays the analysis of these devices in the speech concerned. 
The main criterion of data collection was to choose a speech that was addressed during a critical and memorable moment in the history of South Africa. Accordingly, the sampling of the study is selected from Mandela's No Easy Walk to Freedom which was delivered in 1953 to a rally of 10,000. The essential message of this address, which had profound impact on the social and political life of South Africans, is to call for protesting campaign wherein desegregation and democracy were the basic demands of the protesters (Dennenberg, 2014). It is available at (https://www.mandela.gov.za/Mandela_speeches/ before/ 530921. tranvaal. htm). See also Faris et al (2016) for the entire speech.

\section{Results and Discussion}

Excerpts from the given speech of Mandela are analyzed and discussed in terms of ideological strategies (Actor Description, Positive self-presentation, Negative other- presentation) and discursive strategies (Argumentation and Perspectivation).

\subsection{Ideological Strategies}

\subsubsection{Actor Description}

Example 1

25 The government launched its reactionary offensive and struck at us.

26 Between July last year and August this year forty-seven leading members from both Congresses in Johannesburg, Port Elizabeth and Kimberley were arrested, tried and convicted for launching the Defiance Campaign and given suspended sentences ranging from three months to two years on condition that they did not again participate in the defiance of the unjust laws.

27 In November last year, a proclamation was passed which prohibited meetings of more than ten Africans and made it an offence for any person to call upon an African to defy.

28 Contravention of this proclamation carried a penalty of three years or of a fine of three hundred pounds.

29 In March this year the Government passed the so-called Public Safety Act which empowered it to declare a state of emergency and to create conditions which would permit of the most ruthless and pitiless methods of suppressing our movement.

In this extract, Mandela gives concrete description of the oppressive measures and policies practiced by the apartheid forces against the Africans who have determined to sustain anti-apartheid defiance until achieving the final goals of the nation. What is prominent in this extract is that two cross groups can be identified. One group is represented by the black people who defy the different forms of oppression and injustice. The second group is represented by the white racial authorities who seek to impose their domination over the blacks. In line 25, Mandela attempts to polarize his audience by utilizing the pronoun "us". Utilizing this pronoun may help the speaker to create a sense of unified interaction with his receivers, it may ultimately commit both the speaker and receivers to attain their achievable goals. Van Dijk (1998) expresses that the technique of $U_{s}$ and Them is utilized by politicians as an expression of polarized cognition. Similar findings were made by Allen (2007) when he investigated the way that the two Australian politicians John Howard and John Lathan utilized the pronouns "Us" and "Them" in their speeches during their election campaign. The findings of the study showed that the employment of these two pronouns was a demonstration of the two leaders' political inclusion and exclusion and a reflection of their intention to create a sense of oneness with their political groups.

Attempting to reveal the unjust and inhuman acts of the out-group, Mandela utilizes numbers to assert a high degree of credibility and objectivity, as in "forty seven", "three months" and "two years" in line 26, "ten Africans" in line 27, and "three years" and "three hundred pounds" in line 28. Van Dijk (1998, p.79) says: "Numbers and statistics are primary means in our culture to persuasively display objectivity". Mandela, via the manipulation of numbers, tries to reveal himself as an enthusiastic and resourceful leader who is highly concerned with the details of both the anti-apartheid defiance campaign of the Africans and the reactionary offensives of the apartheid authorities. Equally significant, employing numbers, as a way of vital information, may help Mandela to raise the level of understanding of his masses in regard to the nature of the oppressive political system of South Africa. Leaders, according to Bourdieu (1991)(cited in Meadows, 2009) coin linguistic and semiotic images of the self and connect them with the objectives and aspirations of their audience through the power of discourse.

Mandela, in line 29, refers to the "Public Safety Act", in March 1953, which empowers the racial government to declare a state of emergency. Via the use of the synonymous adjectives "ruthless" and "pitiless", in line 29, Mandela tries to emphasize the idea that the "Public Safety Act" is one of flagrant breaches of human rights exercised by the apartheid state. Van Dijk (1998) expresses that politicians employ lexemes which intensify the negative characteristics of the outgroup.

Mandela, in line 29, presupposes that the "Public Safety Act", which has been perpetrated by the apartheid regime, is one of the gross abuses of human rights. Presupposition, according to Simpson and Mayr 2010, is a linguistic strategy that is utilized in political discourse when politicians involve their receivers to deduce meaning and make assumptions while they deliver information. 
Mandela appears to be certain that all the policies and measures of the white governments are suppressing and unjust as they do harm, degradation, and exclusion for the majority of the nation. To confirm bias to his cause, he utilizes the technique of "vagueness" (Van Dijk, 1998, p. 84) by employing the superlative form of the adjectives "ruthless" and "pitiless" in line 29, "the most ruthless and pitiless", to emphasize the tremendousness of the suppressing policies exercised by the apartheid regime against the African protesters and their leaders.

\subsubsection{Positive Self-Presentation}

Example 2

110 But in spite of all the difficulties outlined above, we have won important victories.

111 The general political level of the people has been considerably raised and they are now more conscious of their strength.

112 Action has become the language of the day.

113 The ties between the working people and the Congress have been greatly strengthened.

114 This is a development of the highest importance because in a country such as ours a political organisation that does not receive the support of the workers is in fact paralysed on the very ground on which it has chosen to wage battle.

115 Leaders of trade union organisations are at the same time important officials of the provincial and local branches of the ANC In the past we talked of the African, Indian and Coloured struggles.

116 Though certain individuals raised the question of a united front of all the oppressed groups, the various non-European organisations stood miles apart from one another and the efforts of those for co-ordination and unity were like a voice crying in the wilderness and it seemed that the day would never dawn when the oppressed people would stand and fight together shoulder to shoulder against a common enemy.

117 Today we talk of the struggle of the oppressed people which, though it is waged through their respective autonomous organisations, is gravitating towards one central command.

Mandela attempts to deepen the relations between him and the masses and maintain the flesh-and-blood ties between the African National congress (ANC), and the masses. Despite the severe measures of oppression and suppression of the racial forces, the African protestors are resolved to break down the strongholds of racial domination. Mandela, in this extract, is interested in presenting positive description of the in-group (the anti-racial protesters) and appears to be so proud of the victories they have made (see line 110 "But in spite....... important victories").

Van Dijk (2001) explains that ideologies are manifested when there is polarization of thought, opinions, or discourse. It is during this process of polarization, prejudiced discourse, which is characterized by positive self-presentation, emerges. In an endeavor to adhere to the masses, Mandela utilizes the strategy of self-glorification, in line 111 "The general political..... their strength", when he states that the public have developed political awareness in regard to their life under apartheid. They have started to move and take initiative and action against the different forms of discrimination and injustice. The use of this strategy was also discovered by Taghinezhad (2015), who highlighted the ideological technique of self-glorification in Obama's inaugural speech; he found that Obama was attentive to proudly talking about the American history of democracy and liberalism.

Mandela believes that the gulf between the public and racial authorities has become evident. Accordingly the African people have succeeded to deal effectively with different challenges and have been able to achieve one breakthrough after another. Barber and Barratt (1990) express that the African National Congress (ANC), presided by Nelson Mandela in 1950s, advocated the strategy of non-violence which involved strikes, boycotts, and other acts of civil disobedience. These acts came to be known as defiance campaign which was not directed against a particular color or race but it was a response against social chaos, tyranny and the unjust laws which imposed the majority of population to live in utter misery and subjection.

Having been influenced by the ideologies of communism, Mandela seems to be highly interested in the working class. The African workers, according to him, can play vital role in the defiance campaign as they pose the majority of the African population. They are described by Mandela as "oppressed" inasmuch as they are targeted by the unfair and inhuman measures of the apartheid state(see lines 116 and 117). To shed much light on the policy of oppression that the racial forces have exercised against black people in general and black workers in particular, he repeats the word "oppressed" five times in the speech (see lines 101, 107, 116, 117, 162). According to Holmes (2009), the term "working people" refers to the overwhelming majority of society rather than to the factory or industrial workers. In Marxist terms, the working class, which is self-conscious and independent as it represents the immense majority of society, has the right to take over the running of society. Obviously, Mandela praises the strong ties that have been held between the working class and the African National Congress (the anti-racist resistance movement) (see line 113 " The ties........ greatly strengthened"). Van Dijk (1998) states that the strategy of positive self-presentation involves a variety of forms; one of these forms is self-glorification. In the above example, Mandela, being very aware of the leading role of the working class, glorifies the great sacrifices of the African workers for the cause of liberty and freedom (see line 114). The African workers, according to Barber and Baratt (1990), maintained a long struggle against 
the apartheid authorities. It was a struggle between the exploiter (racial governments) and the exploited (the working class) who had nothing to win except the free world. The significance of working people, according to Mandela, lies in their power to affect the economy of the racial state, namely when they go on general strikes. They are the basic part of any mass movement aiming to resist the racist state.

Drawing a comparison between the past and present anti-racial struggle, Mandela believes that past anti-racial struggle has been fruitless because it has lacked unity and coordination. On the contrary, he is full of praise of the present struggle wherein different Non-European anti-racial movements have unified, coordinated and organized their efforts to confront the threats and challenges of the apartheid state (line 117 "Today we talk...... central command").

\subsubsection{Negative Other-Presentation}

Example 3

75 The Government has introduced in Parliament the Native Labour (Settlement of Disputes) Bill and the Bantu Education Bill.

76 Speaking on the Labour Bill, the Minister of Labour, Ben Schoeman, openly stated that the aim of this wicked measure is to bleed African trade unions to death.

77 By forbidding strikes and lockouts it deprives Africans of the one weapon the workers have to improve their position.

78 The aim of the measure is to destroy the present African trade unions which are controlled by the workers themselves and which fight for the improvement of their working conditions in return for a Central Native Labour Board controlled by the Government and which will be used to frustrate the legitimate aspirations of the African worker.

79 The Minister of Native Affairs, Verwoerd, has also been brutally clear in explaining the objects of the Bantu Education Bill.

80 According to him the aim of this law is to teach our children that Africans are inferior to Europeans.

81 African education would be taken out of the hands of people who taught equality between black and white.

82 When this Bill becomes law, it will not be the parents but the Department of Native Affairs which will decide whether an African child should receive higher or other education.

83 It might well be that the children of those who criticise the Government and who fight its policies will almost certainly be taught how to drill rocks in the mines and how to plough potatoes on the farms of Bethal.

84 High education might well be the privilege of those children whose families have a tradition of collaboration with the ruling circles.

Part of negative other-presentation, Mandela is involved in talking about the racial measures of the government, namely the Native Labor Settlement of Dispute Act which was introduced to the parliament by the government in 1953 (see line 75).Mandela endeavors to describe the unjust measures of the racial authorities. To emphasize his negative views on the discriminatory and oppressive methods of the racial state; he uses the adjective "wicked" repetitively in the speech. It can be seen in lines 76 and 105. It could also be observed that Mandela, in the above example, uses the antonyms "wicked" (line 76) and "legitimate" (line 78) to draw a distinction between two opposite directions, the wicked measures of the racial state and the legitimate aspirations of the black workers.

Highlighting the sufferings and miseries of the blacks because of the full domination of the white governments, Mandela makes a mention to one glaring example of the machinery of oppression and repression of the racial state which was the enactment of the Native Labor Bill (see line 76) which legalized the crackdown of the African workers by banning them to go on strikes or lockouts (Giliomee, 2009). Workers who intended to breach it would be either fined $\$ 500$, or imprisoned for three years. Despite receiving a great level of opposition, this act illegalized the South African Unions for their anti-racial activities.

Mandela appears to be ironic when talking of Ben Schoeman, the Minister of Labor. What is ironic in this context is that instead of acting to ensure the safety conditions and rights of the African workers and African Trade Unions, Schoeman undertakes unfair and inhuman measures against them (see line 76). Despite the fact that Schoeman knew very well that Native Labor Bill had been enacted to cripple the anti-racial activities of the African Trade Unions, which were controlled by the African workers, he ironically claimed that the Africans' poor experience of the responsibilities of Trade Unionism was the real reason behind the enactment of such Act (Clark and Worger, 2011).Hutcheon (1994) states that examples of the scene of irony are concentrated in political speeches, especially those which tackle issues of race and class.

The Native Labor Act, according to Durbow (2014), denied the black Africans the right to resist the demands of their European employers under any circumstances. Employing the word "wicked" (line 76) Mandela tries to emphasize the idea that the Native Labour Act is a glaring violation of workers' rights because strikes and lockouts are the only path 
through which workers may improve their conditions by calling for their plundered rights (line 77).Mandela degrades Schoeman for his open statement that the aim of Native Labor Bill is to destroy the African Trade Unions as they motivate African workers to go on strike and lockout (line 78). Targeting the African Trade Unions, according to Mandela, is a targeting of the legitimate dreams and aspirations of the African workers who cover a high proportion of the black population.

In addition to the Native Labor Act which reflect the aggressive and discriminatory nature of the apartheid, Mandela refers to the Bantu Education Act which is a flagrant attack against the right of the blacks to get good education (line 79). Based on this act, it could be realized that education is segregated because educational facilities are separated. The whites have the full right to obtain a high level of education, whereas the blacks have to be prepared as laboring class. Mandela makes a reference to Verwoerd (known to be the mastermind of apartheid (Burnell, 2010)), who clearly declares the unjust objectives of Bantu Education Act (line 80). According to Mandela, Bantu Education Act is a striking reflection of the ideology of white supremacy. In line 81 , he uses the antonyms "black" and "white" to emphasize the idea that blacks have been treated as inferior in nature to the white. For this reason, he repeats the word "supremacy" four times in the speech to emphasize the theme that "white supremacy" is the ideological basis of the European policies of extension, racism and colonialism across the world (see lines $93,95,96,97$ ). It has been publically advocated as the overall ideology of the racial authorities of South Africa. For example, the Minister of Native Affairs, Hendrik Verwoerd, has openly stated that blacks have no place in European communities and their education is in vain since they are not allowed to practice it in real life. The black Africans, according to him, are fit only for the laboring market (Clark and Worger, 2011). Spotting light on the potency of lexical repetition to reveal the implied ideologies in Obama's inaugural speech, Horvath (2009) found that the word "America" was utilized repetitively by Obama to emphasize his inclusiveness and recognition of the American nation and American culture.

It could be observed that Mandela uses the words "wicked", in line 76, and "brutally", in line 79, to describe the unjust and inhuman policies of the racial authorities. Utilizing such words, Mandela tries to direct the attention of his receivers to the unrestricted domination of the ideology of white supremacy in a country which is inhabited by black majority. According to Mandela, Bantu Education Bill is predominately aggressive as it confirms the feelings of inferiority in the psyche of the black Africans (line 80). Emphasizing the feelings of inferiority which is deeply rooted in the very structure of the black community, Mandela uses the word "inferior" three times in the speech (see lines $62,80,137$ ). It could be realized that the unjust nature of Bantu Education Bill implies that racial authorities are the only hand which can decide whether a black child can have higher education or not (line 82). As a discriminatory and antagonistic method practiced by the racial authorities against the black, the children whose families collaborate with the racial government are allowed to obtain their higher education, whereas those children, whose families are opposed to the government, are prohibited to have higher education. Thus, they are doomed to practice hard works on farms or in mines (line 83).

Fredrickson (1982) states that the ideology of white supremacy, which paved the way for the domination of the white minority over the black majority in South Africa, enabled the whites to control the minerals which were considered to be the base of the industrial revolution. Controlling the mineral areas as well as planning to keep the Africans in poor conditions, the racial authorities denied Africans their legitimate right to own land in areas occurring outside their overcrowded reserves, a policy which established the patterns of racial discrimination and created the phenomenon of black labor exploitation for the advantage of the white landlords and white economy. The strong desire of the whites to own land and their rooted belief that the blacks are less fully human or they are no more than savages made them unable to distinguish between basic rights and violations of human rights. They were on the firm conviction that enslaving Africans and usurping their lands was part of their basic rights. By time they forced their will upon the overwhelming black majority via master-slave relationship and imposed their absolute domination over all aspects of life for decades. Burnell (2010), on his part, believes that the long-term and consistent measures of oppression, repression, injustice, and negligence against the black for centuries have driven the blacks to suffer from intensifying feelings of inferiority resulting in them having had low self-esteem, low self-worth, and low socio-economic status.

\subsubsection{Argumentation}

Example 4

40 The Congresses realised that these measures created a new situation which did not prevail when the Campaign was launched in June 1952.

41 The tide of defiance was bound to recede and we were forced to pause and to take stock of the new situation.

42 We had to analyse the dangers that faced us, formulate plans to overcome them and evolve new plans of political struggle.

43 A political movement must keep in touch with reality and the prevailing conditions.

44 Long speeches, the shaking of fists, the banging of tables and strongly worded resolutions out of touch with the objective conditions do not bring about mass action and can do a great deal of harm to the organisation and the struggle we serve.

The masses had to be prepared and made ready for new forms of political struggle. 
As a leader, Mandela, in this extract, gives his receivers two underlying justifications for the recession of the defiance campaign which was launched in June 1952. The first is that the leaders of defiance campaign were in confrontation with dangers which needed to be analyzed(line 42)("We had...faced us"). This justification reveals that Mandela has a high level of self-awareness and social awareness. Self-awareness, according to Twain(2014), is a strategy through which a person can determine his own strength and weaknesses. This strategy can help an individual to overcome his weak points; it may also provide him with an opportunity to make him have positive influence on others. Social awareness, on the other hand, reflects the ability of an individual to understand others. Mandela appears to be fully aware of the causes behind the trauma that struck the defiance campaign. As a strategic leader, he, accordingly, tries to set and develop new strategies for challenging the dangers that faced the persistent anti-racial struggle. Leadership, according to Northhouse (2015), can be measured throughout self-awareness, charisma, as well as the sacrifices that leaders should produce for the sake of their peoples' freedom.

The second justification behind the awkward situation of the defiance campaign, as diagnosed by Mandela, is that the African National Congress, running the defiance campaign, lacked in realism (line 43). Mandela is of the view that the leaders of the defiance campaign should not risk by embarking on unknown path during their struggle. According to him, they have to practice realism and prudence in order to achieve the objectives of the struggle. Being a practical leader, Mandela calls upon realism as a conscious approach of fighting the racial forces. He, therefore, criticizes the lengthy bombastic speeches, shaking of fists, banging of tables, and rash resolutions which do not bring about a truly positive change in the life of the oppressed black Africans (line 44 "Long speeches...worded resolutions"); rather, they may lead to more harm and vulnerability to the African National Congress.

Delving into the aforementioned extract, it could be realized that Mandela attempts to implement political incorporation, representation, and influence. He shows himself as a strategic and challenging leader who is able to diagnose the points of weaknesses, and then he intends to remedy them through new forms and tactics of fighting. Sampson(2011) characterizes four attributes for Mandela. They are: anticipation, challenging, interpretation, and learning. Firstly, Mandela is skilled at anticipating future events that have something to do with present ones. Secondly, he has profound willingness to sacrifice for the sake of his beliefs and he has extraordinary insistence on challenging, by means of deed and action, those who have dehumanized and persecuted his people and denied them the legitimate rights of freedom, dignity, and social equality. Thirdly, he shows great ability of interpreting the underlying objectives of the racial policies. Fourthly, he always makes use of his past falls and experiences and never hesitates to learn from the experiences and falls of others.

It could be realized that the defiance campaign, oppressed severely by the racial forces (line 40), came as a result of the policies of discrimination and exclusion that black Africans had suffered for a long time. Hence, it is this feeling of social and political exclusion which has created the division between "Us", the black Africans, and "Them", the racial authorities.

Mandela, in the extract above, appears to be fully aware of the depth and nature of the constantly exclusionary policies of the racial regime. Therefore, he works hard to mobilize the nation to defiance campaign through which they may voice their resistance to all facets of exclusion. The increasingly oppressive measures of the racial forces have urged Mandela and his comrades to formulate and develop the strategies of opposition (line 42 "...formulate plans...political struggle"). The feeling of being excluded, which he shares with his nation, has enabled him to address his people to be prepared for new forms of battling (line 45). The policies of marginalization, according to Feldman (2006), are based on either color, race, ethnicity, gender, or religion and results in a social and political dilemma or stigma.

\subsubsection{Perspectivation}

Example5

1 Since 1912 and year after year thereafter, in their homes and local areas, in provincial and national gatherings, on trains and buses, in the factories and on the farms, in cities, villages, shanty towns, schools and prisons, the African people have discussed the shameful misdeeds of those who rule the country.

2 Year after year, they have raised their voices in condemnation of the grinding poverty of the people, the low wages, the acute shortage of land, the inhuman exploitation and the whole policy of white domination.

3 But instead of more freedom repression began to grow in volume and intensity and it seemed that all their sacrifices would end up in smoke and dust.

It could be observed that Mandela, in the speech under investigation, attempts to report a series of significant incidents. He appears to be highly careful in transmitting accurate and constructive information concerning the inhuman policies of the racial governments. Harrington (1997) believes that that the term "report" can be used to refer to any informational work designed to restate or reconsider certain events or realities in a concrete presentable form. Reports, according to Harrington (1997), are significant because they are strong enough to display the results of one's own experiment or investigation on the condition that the elements of credibility, neutrality, verification, and accuracy should be available. 
To achieve credibility and to evoke the emotional texture of his masses, Mandela reports about places and people in documentary details. In line 1, for example, he gives the exact time when the African people have started inquiring about the unscrupulous policies of the ruling authorities of South Africa, "Since the year 1912". Thompson (2000) expresses that the formation of African National Congress in 1912 is a significant turning-point in the history of South Africans. It was a response to the systematic operations of racial inequality and injustice exercised by the white racial governments against the black Africans.

In line 2, he tries to focus not only on producing facts but also on creating involvement throughout these facts, especially when he intensifies that South Africans' resentment and condemnation towards the cruel measures of the racial governments have spread throughout the whole country (line 1 "...homes...school and prisons"). In in-depth reporting, he identifies five causes which have contributed to incite the African masses against the racial authorities: the abject poverty, the low wages of the African laborers, the shortage of land, the unjust exploitation of the Africans, and the overall strategy of domination (line 2 "....the grinding poverty...of domination"). To strengthen the social fabric of the African masses and to connect them emotionally, he reports the fact that the measures of oppression and repression, exercised by the racial authorities against the African people, have been intensified, (line 3). It could be recognized that Mandela, in this extract, reports facts that should attract the attention of the masses and encourage them to make decisions that may change their social and political realities.

\section{Conclusion}

Having looked carefully into Mandela's No Easy Walk to Freedom, it could be recognized that it was centered around two contrasting underlying ideologies which are white superiority and black inferiority. White superiority was the ideological foundation of the whites to sustain different policies of problematization, exclusion, and injustice which controlled and shaped the social acts and practices of the black Africans for decades. Black inferiority, on the other hand, was the ideological foundation of the blacks to maintain different forms of challenge and resistance against the whites' measures of exploitation and domination. The social representation of blacks and whites, manifested in the speech, was based on intensifying the bad characteristics and attributes of the whites (the out-group) and emphasizing the good acts and characteristics of the blacks (the in-group).Mandela's ideologies and ideological strategies, which are evident in the speech under investigation, are shown in Table 2.

Table 2. Ideologies and Strategies in Mandela's No Easy Walk to Freedom

\begin{tabular}{|c|c|c|c|c|}
\hline \multicolumn{5}{|c|}{$\begin{array}{l}\text { Ideologies embedded in Mandela's discourse } \\
\text { White Superiority versus Black Inferiority }\end{array}$} \\
\hline \multicolumn{5}{|c|}{ Mandela's Ideological Strategies and Devices } \\
\hline $\begin{array}{l}\text { Actor Description } \\
\text { (Identifying the in- } \\
\text { group and the out- } \\
\text { group) }\end{array}$ & $\begin{array}{l}\text { Positive Other- } \\
\text { Presentation } \\
\text { (In-group } \\
\text { Favoritism) }\end{array}$ & $\begin{array}{l}\text { Negative Other- } \\
\text { Presentation } \\
\text { (Out-group } \\
\text { Derogation) }\end{array}$ & $\begin{array}{c}\text { Argumentation } \\
\text { (Justification) }\end{array}$ & $\begin{array}{l}\text { Perspectivation } \\
\text { (Social and Political } \\
\text { exclusion or Inclusion) }\end{array}$ \\
\hline $\begin{array}{l}\text { - Utilizing the } \\
\text { pronoun } U s \text { and } \\
\text { Them to polarize the } \\
\text { blacks } \\
\text { - Utilizing numbers } \\
\text { and statistics to } \\
\text { stress interest in the } \\
\text { status quo issues of } \\
\text { the blacks } \\
\text { - Presupposing the } \\
\text { threats of the racial } \\
\text { measures to the life } \\
\text { and dignity of the } \\
\text { blacks } \\
\text { - Employing vague } \\
\text { superlative forms of } \\
\text { adjectives to show } \\
\text { bias to the blacks } \\
\text { (the ingroup) }\end{array}$ & $\begin{array}{l}\text {-Showing a sense } \\
\text { of self-glorification } \\
\text { by referring to the } \\
\text { heroic anti-racial } \\
\text { response of the } \\
\text { blacks and praising } \\
\text { their rising level of } \\
\text { consciousness } \\
\text { toward the racial } \\
\text { policies }\end{array}$ & $\begin{array}{l}\text {-Utilizing irony } \\
\text { to sarcastically } \\
\text { describe the } \\
\text { racially double- } \\
\text { standard } \\
\text { measures of the } \\
\text { whites towards } \\
\text { the black } \\
\text { workers } \\
\text {-Utilizing } \\
\text { specific lexemes } \\
\text { to highlight the } \\
\text { tragedies of the } \\
\text { blacks }\end{array}$ & $\begin{array}{l}\text {-Developing } \\
\text { self and social } \\
\text { awareness by } \\
\text { justifying the } \\
\text { points of } \\
\text { weakness of } \\
\text { the blacks' } \\
\text { anti-racial } \\
\text { defiance } \\
\text { campaign }\end{array}$ & $\begin{array}{l}\text { - Reporting incidents } \\
\text { on the unjust policies } \\
\text { of the apartheid to } \\
\text { create involvement by } \\
\text { evoking theemotional } \\
\text { texture of the blacks. }\end{array}$ \\
\hline
\end{tabular}

Two groups of actors can be identified in the speech under analysis. One group (i.e. the in-group), whom Mandela joined and backed, was represented by the black Africans who endeavored tirelessly to gain freedom, selfdetermination, empowerment, and liberation although they had faced severe and pitiless measures of oppression and injustice. The second group (i.e. the out-group) was represented by the racial authorities who sought to impose their domination over the blacks. To maintain a linguistic and semiotic image whereby he could mobilize his receivers, 
Mandela employed the pronoun "Us" to confirm a high sense of inclusion and unification with the in-group, manipulated numbers to achieve credibility and reliability, used vague expressions to indicate bias in favor of the ingroup, and made reference to authority figures to back his information and opinions. Via the strategy of actor description, Mandela produced evidences of the bad attributes and acts of the out-group members (for instance, when he made a reference to their oppressive policies, such as " The Public Safety Act", in 1953, by means of which the government was empowered to take any oppressive measure against the anti-racial resistance movements, and "The Criminals Laws Amendment Act" which imposed heavy penalties on those who were convicted of defiance offences).

Through the strategy of positive self-presentation, Mandela attempted to deepen the relation between him and his audience by polarizing their cognition on the racial policies of the white government, glorifying their development of political awareness towards the policies of racial segregation, and comparing their legitimate and heroic acts with the illegitimate and cruel acts of the racial authorities.

In an attempt to present the out-group negatively, Mandela highlighted the tragedies and misfortunes inflicted upon the black people by the racial authorities who had practiced different measures of dehumanization and boundless policies of domination. An example of the dehumanizing measures of the racial state was the "Bantu Education Bill" which restrained the black children to complete their education believing that they were not fit for education as much as for the labor market. It could be recognized that Mandela, via the strategy of negative other-presentation, deplored the ideology of white supremacy which echoed a glaring violation of human rights and dignities.

Through the strategy of argumentation, Mandela developed a sense of self-awareness, identifying one's own positions of weakness and strength, and social-awareness, the ability of an individual to understand others, while he attempted to set justifications for the recession of the defiance campaign. Showing himself a pragmatic and strategic leader who was able to diagnose the weaknesses of the in-group and prescribed a remedy for them, Mandela called for a conscious approach of fighting the racial state wherein realistic tactics and strategies were to be adopted. By means of the strategy of argumentation, Mandela emphasized the concept of political and social exclusion. He appeared to be fully aware of the depth and nature of the racial exclusionary policies which denied the black population any political or social representation. Political and social exclusion, as a paradigmatic form of injustice, revealed unequal relationship between the dominated, the black, and the dominator, the racial authorities; a relationship that was based on a deeprooted ideology of white supremacy and black inferiority.

Using the strategy of perspectivation, Mandela reported details of incidents with the purpose of creating involvement. The incidents that he reported were about the unjust measures of the racial state. Reporting them could have helped him to strengthen the social fabric of the blacks and get them engaged in the racial inequalities and injustices that were practiced by white authorities. In addition to involvement that this strategy might result in, reporting, as a popular technique of discourse incorporating a high sense of credibility, neutrality, verification, and accuracy, may have helped to consolidate the relationship between Mandela and his masses.

\section{References}

Abercrombie, N., Hill, S. \& Turner, B. (1980). The dominant ideology thesis. London: Allen\&Unwin.

Allan, W. (2007). Australian political discourse: Pronominal choice in campaign speeches. Applied Linguistics, pp. 213.

Barber, J. and Baratt, J. (1990). South Africa's foreign policy: The Search for status and security, 1945-1988. New York: Cambridge University Press.

Blair, T. (2003).Tony Blair's speech on the Iraqi crisis. Retrieved from www.the Guardiancom/politics/2003/mar/foreignpolicy.iraq.

Burnell, T. (2010).Brainwashed: Challenging the myth of black inferiority. New York Smiley Books.

Clark, N. \&Worger, W. (2011).South Africa: The Rise and Fall of Apartheid. London: Routledge.

Coulthard, M. (1977).An introduction to discourse analysis. London: Longman.

Durbow, S. (2014). Apartheid 1948-1994. Oxford: Oxford University Press.

Fairclough, N. (1989). Language and power. New York: Longman Group Limited.

Fairclough, N. (1995). Critical discourse analysis: The critical study of language. London: Longman Limited Group.

Faris, A., Paramasivam, S., Tan, B.H. \& Abdul, M.Z. (2016). Persuasive strategies in Mandela's No Easy Walk to Freedom. International Journal of Applied linguistics and English Literature, 5(1), pp. 192-203.

Feldman, L. (2006). Citizens without shelter: Homelessness, democracy, and political exclusion. London: Cornell University Press.

Fredrickson, G. (1982). White Supremacy: A comparative study in American \& South African history. Oxford: Oxford University Press.

Georgakopoulou, A. \& Goutsos, D. (1997). Discourse analysis: An Introduction. Edinburgh: Edinburgh University Press.

Giliomee, H. (2009). A Note on bantu education 1953-1970. South African Journal of Economics, 77, pp. 190-198. 
Halliday, M. A. K. \& Hassan, R. (1976). Cohesion in English. London: Longman.

Harrington, W. (1997).Intimate Journalism: The art and craft of reporting everyday life. London: Sage.

Harvath, J. (2009). Critical discourse analysis of Obama's political discourse. Topics in Linguistics, pp. 45-56.

Holmes, L. (2009).Communism: A very short introduction. Oxford: Oxford University Press.

Hutcheon, L. (1994). Irony edge: The theory and practice of irony. London: Routledge.

Janks, H. (2002). Critical discourse analysis as a research tool. Critical discourse analysis: Critical Concepts in Linguistics, pp. 26-42. New York: Routledge.

Johnstone, B. (2008). Discourse analysis. Oxford: Blackwell Publishing.

Kress, G. (1985). Ideology structure in discourse.Handbook of Discourse Analysis,4, pp, 27-42.

Mandela, N. (1953). No easy walk to freedom: Presidential address by Nelson R. Mandela to the ANC (Transvaal) Congress 21 September 1953. Retrieved Fromhttp://www.sahistory.org.za / archive/no-easy-walk-freedom-presidentialaddress-nelson-r-mandela-anc-transvaal-congress-21-septemb.

Meadows, B. (2009). Capital negotiation and identity practices: Investigating symbolic capital from the ground up. Critical Discourse Studies, 6, pp. 15-30.

Merriam, S. (1983).Qualitative research: A Guide to design and implementation. San Francisco:Jossey-Bass.

Northhouse, P. (2015). Leadership: Theory and practice. Los Angeles: Sage.

Obama, B. (2015).President Obama's 2015 State of the Union Address.Retrieved from www.mediaite.com/online/president-obamas-2015-state-of-the-union-address-full-transcript.

Sampson, A. (2011). Mandela: The authorized biography. London: Harper Collins.

Simpson, P. \& Mayr, A. (2010).Language and power. London: Routledge.

Stubbs, M. (1983).Discourse analysis: The Sociolinguistic analysis of natural languages.Oxford: Blackwell.

Thatcher, M. (2008).Thatcher's speech to the college of Europe:The Bruges Speech.Retrieved from www.telegraph.co.uk/comment/personal-view/3562258/Full-Text-of-Margret-Thatchers-Speech-to-the-College-ofEuropr-The-Burges-html.

Taghinezhad, A. (2015). Persuasive strategies used in Obama's political speech. Journal of Applied Linguistics and Language Research, pp. 13-27.

Thompson, L. (2000). A history of South Africa. New York: Yale University Press.

Twain, A. (2014).Self awareness. London: Kindle Unlimited Press.

Van Dijk, T.A (1998). Ideology: A multidisciplinary approach. London: Sage.

Van Dijk, T. A (2001).Discourse, ideology and context. Folia Linguistica, pp. 11-40.

Van Dijk, T.A.(2004). Politics, ideology and discourse. Encyclopedia of language and Politics, pp.1-27.

Wodak, R. \& Meyer, M.(2001). Methods of critical discourse analysis. London: Sage.

Wodak, R. (2005). Feminist critical discourse analysis: New perspectives for interdisciplinary gender studies. In Symposium on CDA: Feminist CDA and and interdisciplinary; right wing populism local answers to global issues. Retrieved from www.isotita.uoa.gr/.../200405//11\%20perilispi\%20Wodak Ruth.doc.

Wodak, R. (2007). What is critical discourse analysis? In Conversation with Gavin Kendell, R. [38 paragraph].Forum qualitative sozialforeshing: Qualitative Social research,8. Retrieved from www.qualitativeresearch.not/fqtext/2-07-229e.htm. 
Appendix

Table 1. Ideological Themes in Mandela's No Easy Walk To Freedom

Ideological Analytical Techniques

Themes

Freedom

Lexical Repetition

freedom (lines 3,19, 55, 90, 102, 108, 162, 171, 174)

Meaning Relations

Synonymous Nouns :awakening $=$ consciousness (line 5 )

Antonymous Nouns: freedom (line 171) x oppression ( line 157), liberation x repression (line104)

Defiance $\quad$ Lexical Repetition

defiance (lines 12, 22, 26, 30, 32, 41, 49, 52), indignation (lines 14, 106, 165)

Meaning Relation

Synonymous Nouns: discontent (line 100) = indignation (106)

Antonymous Adjectives: conquered x uncompromising (line 16)

Oppression

Lexical Repetition

oppressed (lines: 101, 107, 116, 117, 162), inhuman (lines 2,108, 140)

Meaning Relation

Synonymous Adjectives: ruthless = pitiless ( line 29), insane $($ line 65$)=$ obnoxious $($ line 74$)=$ sinister $($ line $88)=$ harsh $($ line 105) $=$ stinking $($ line 109) $=$ inhuman $($ line 140$)=$ barbaric $($ line 140 $)=$ criminal $(1$ ine 163)

Antonymous Nouns: oppression (line 156) x freedom (line 3), repression x liberation (104)

Hyponyms: suppression (line 33), unemployment (line 62), hunger (line 69), exploitation (line 88), repression (line 104), discrimination (line 162), slaughter (line 165), massacre (line 166), atrocities (line 170)

\begin{tabular}{ll}
\hline Supremacy & Lexical Repetition \\
& supremacy (lines: 93, 95, 96, 97) \\
& Meaning Relation
\end{tabular}

Hyponyms: suppression (line 33), unemployment (line 62), hunger (line 69), exploitation (line 88), repression (line 104), oppression (line 157), discrimination (162), slaughter (line 165), massacre (line 166), atrocities (line 170) 